\title{
Spilt kunnskap på lektorutdanninga
}

\author{
Førsteårsstudentenes erfaringer med «Kunnskapsspillet»
}

\author{
Astrid Strandbu ${ }^{1}$, Jørn Weines ${ }^{2}$, Margrethe Esaiassen ${ }^{2}$ \\ 1: Institutt for laererutdanning og pedagogikk, UiT Norges arktiske universitet, 9037 Tromsø \\ 2: Norges fiskerihøgskole, UiT Norges arktiske universitet, 9037 Tromsø
}

\begin{abstract}
SAMMENDRAG: Forskning viser at læringsmetoder som engasjerer studentene kan bidra til økt læringslyst og læringsutbytte. Et eksempel er bruk av spill som pedagogisk virkemiddel. Ved lektorutdanninga 8-13 ved UiT har Kunnskapsspillet stått sentralt i kvalitetsutviklingen av et førstesemesteremne i pedagogikk hvor formålet var å styrke profesjonsrelevans og økte studentenes trivsel og trygghet. I artikkelen undersøkes hvordan spillbasert læring bidrar til læringsutbytte, og hvilke kvaliteter studentene erfarer gjennom bruken av spillet. Artikkelen er teoretisk forankret i sosiokulturell læringsteori. Datamaterialet er evalueringer fra 274 studenter fra tre kull. Resultatene viser at studentene er positive til anvendelsen av spillet og erfarer at spillet bidrar til læringslyst, læringsutbytte og opplevelse av meningsfull sammenheng. I artikkelen diskuteres kvaliteter ved bruk av spillet og profesjonsrelevans. I videre styrking av læringslyst og læringsutbytte er det viktig å fokusere på frekvens ved anvendelse av spillet og underviserens rolle i læringsprosesser med spillbasert læring. ${ }^{1}$
\end{abstract}

Nøkkelord: Constructive alignment, læringslyst, læringsutbytte, meningsfull sammenheng, spillbasert læring

\footnotetext{
${ }^{1}$ Takk til fagfelle og redaksjonen i tidsskriftet for nyttige innspill i revidering av artikkelen.
} 


\section{INTRODUKSJON}

Ulike former for aktiv læring, som stimulerer studentenes engasjement, motivasjon og læringslyst, kan bidra positivt til læringsutbytte (Biggs \& Tang, 2011; Prince, 2004; Jakobsen \& Waldenstrøm, 2017). Et eksempel er bruk av spill i undervisningen. Spill og spilling er kjent for de fleste. Dette åpner for spill som et pedagogisk virkemiddel. Spill som læremiddel benevnes på ulike måter, blant annet som spillbasert laering. I spillbasert læring brukes spill som en del av læringssituasjonen for å strukturere arbeidet og forbedre og styrke studentenes læringsutbytte (Wiggins, 2016). Spill vil ikke erstatte annen undervisning, men spillelementer kan kombineres med fagstoff $i$ en læringsprosess hvor både forarbeid og etterarbeid er sentralt (Garris et al., 2002). Gjennom forarbeid og etterarbeid settes spillet inn i den overordnede faglige konteksten for å bidra til refleksjon og læring (Nicholson, 2012; Garris et al., 2002; Crookall, 2010).

Mye av fokuset i forskningen på spillbasert læring har det siste tiåret vært rettet mot digitale spill. Det publiseres nå også mye om bruk av brettspill i undervisning (Boghian et al., 2019; Hoy, 2018). Bridge (2014) argumenterer for flere fordeler ved å lage læringsspill med utgangspunkt i velkjente brettspill. Spill som på overflaten ligner spill studentene kjenner fra før, gjør at det tar mindre tid å forklare regler og det kan produseres mange eksemplarer uten store økonomiske kostnader. I sum gir dette lave oppstartskostnader for både lærere og studenter. Læringsprosessen kan starte fra første terningkast. Ettersom mange grupper kan spille samtidig, uten at underviseren må involveres, er det også lett å anvende slike spill i store studentgrupper.

Denne artikkelen retter fokus mot bruk av brettspill som pedagogisk verktøy i læringsprosessen i et tistudiepoengsemne i pedagogikk første semester ved lektorutdanninga 8-13, UiT Norges arktiske universitet (heretter lektorutdanninga). ${ }^{2}$ En utfordring i studiedesignet ved lektorutdanninga er at studentene på et og samme kull er spredt over fire fakulteter og ni institutter, avhengig av om de har valgt fordypning i språkfag, samfunnsfag eller realfag. Det har vært stort frafall ved utdanninga, slik bildet også er ved mange andre lærerutdanninger (Skrøvset et al., 2017). På studiebarometeret har lektorutdanninga skåret lavt på områdene læringsmiljø og medvirkning, og i evalueringer har studentene uttrykket savn av kullfølelse og fellesskap med sine medstudenter. Lektorutdanninga ved UiT har hatt stor vekst de siste årene. Antall studenter ble nær doblet fra 2016 til 2017, fra 66 til 123 studenter. Med så stor økning kunne det forventes at eksisterende utfordringer ville bli enda mer fremtredende.

Pedagogikkemnet første semester i lektorutdanninga er det eneste emnet de to første studieårene hvor alle studentene på kullet har undervisning sammen. Siden høsten 2017 har det derfor vært satt spesielt fokus på dette emnet. Det er gjort omfattende endringer når det gjelder undervisningsmetoder med innføring av studentaktive læringsformer. Ulike trivselsfremmende tiltak er iverksatt, og fokus i undervisningen er rettet mot styrking av studentenes læringsstrategier og opplevelse av helhet, sammenheng og profesjonsrelevans. I denne artikkelen fokuserer vi på endringer i

\footnotetext{
${ }^{2}$ Emnekoden er PFF-1020, og tittelen på emnet er «Eleven, læring og danning i sentrum».
} 
undervisningsmetoder med innføring av spillbasert læring. To spill er utviklet og tatt i bruk, Etikkspillet og Kunnskapsspillet. Vi avgrenser oss til å fokusere mot bruk av Kunnskapsspillet.

Et formål med artikkelen er å teoretisere spillbasert læring med Kunnskapsspillet som eksempel. Teoretisk plasserer vi oss innen et sosiokulturelt syn på læring (Vygotskij 1978, 2001). Et annet formål er å kaste lys over lektorstudentenes erfaringer med bruken av Kunnskapsspillet. Følgende forskningsspørsmål er stilt:

- Hvordan bidrar bruken av spillbasert læring til å oppnå læringsmålene i pedagogikkemnet første semester på lektorutdanninga?

- Hvilke kvaliteter erfarer studentene gjennom bruk av Kunnskapsspillet i dette emnet?

Det empiriske materialet består i hovedsak av individuelle studentevalueringer fra 274 studenter i kull 2017, 2018 og 2019. Datamaterialet består også av skriftlige referater fra gruppeevalueringer med studentene i de samme kullene og møtereferater fra evalueringsmøter med eksterne sensorer. Skrøvset et al. (2017) peker på lav arbeidsinnsats som en utfordring ved lærerutdanninger og relaterer dette til studentenes laeringslyst. Kirk-Johnson et al. (2019) knytter lav arbeidsinnsats til utfordringer med å velge effektive laeringsstrategier. Spill kan tenkes å være et verktøy som hjelper studentene å strukturere arbeidet med pensum. For å undersøke dette nærmere har vi spurt studentene om egen tilfredshet med å spille Kunnskapsspillet, nytte ved bruk av spillet frem mot eksamen og spillets relevans for egen undervisning som fremtidig lektor. Studentene er i tillegg stilt spørsmål om egeninnsats og trivsel og trygghet ved utdanninga. Sæthre (2014) løfter frem studentens egne drivkrefter og motivasjon, særlig første studieår, som avgjørende for å mestre studiet. For de fleste henger egeninnsats tett sammen med forhold som trivsel, trygghet og læringsmiljø. Spillbasert læring synes å ha et potensiale for å bidra til trivsel og trygghet, ved at studentene kan bli kjent under en lekende samarbeidsform (Plass et al., 2015). Dette diskuteres nærmere i artikkelen.

\section{BAKGRUNN OG BESKRIVELSE AV KUNNSKAPSSPILLET}

Spillrammen i Kunnskapsspillet, med regler og spillmateriell, er utviklet ved Norges fiskerihøgskole ved UiT som spillet «Go'n'fish - fishing for knowledge» i forbindelse med SimFish-prosjektet. ${ }^{3}$ Go' $n$ 'fish ble i 2017 tilpasset lektorutdanninga som Kunnskapsspillet. I fortsettelsen beskrives først spillmateriellet og spillereglene i Go'n' fish. Deretter beskrives hvordan dette undervisningsverktøyet er tilpasset læringsmålene i førstesemesteremnet i pedagogikk ved lektorutdanninga. ${ }^{4}$

\footnotetext{
${ }^{3}$ SimFish er et prosjekt med støtte fra UiTs «Fyrtårnmidler» for nyskapende prosjekter for utvikling av utdanning. Nettside: https://uit.no/prosjekter/prosjektsub?p document id=448448\&sub id=573807

${ }^{4}$ Tredjeforfatter var sentral i utviklingen av spillet «Go'n'fish» ved Fiskerih øgskolen. Førsteforfatter har anvendt spillmaterialet i Go'n'fish i utviklingen av Kunnskapsspillet ved lektorutdanninga.
} 


\subsection{Et fleksibelt mulitverktøy for læring}

Med sitt spillmateriell ligner Go'n'fish spørrespill som mange kjenner til fra før, som for eksempel Trivial Pursuit og Bezzerwisser. Spillmaterialet består av et spillebrett med felt med fire farger (gul, rød, blå og grønn) som lagene flytter rundt på, spørrekort i fire kategorier, en terning og brikker. Hver av de fire kategoriene relaterer seg til læringsmål med tilhørende pensum i emnet spillet anvendes i. Det er også en femte spillkortfarge (svart). Dette er en uhøytidelig kategori som forsterker lekelementet $\mathrm{i}$ spillet. Under spillet kaster studentene terning og flytter lagets spillebrikke i valgfri retning det antall øyne som terningen viser. Laget trekker så et spillkort tilsvarende fargen på spillbrettet som spillebrikken landet på og svarer på spørsmålet. For å kunne gå videre må laget gi et tilfredsstillende svar på spørsmålet. Spillebrettet er utformet slik at én rute av hver farge står i et «veikryss» og har et markert symbol (Se Figur 1). Lagene må svare riktig på spørsmålene i «veikryssene» i alle spillets kategorier for å kunne bevege seg inn mot spillebrettets sentrum. Det laget som er først ved sentrum vinner spillet.

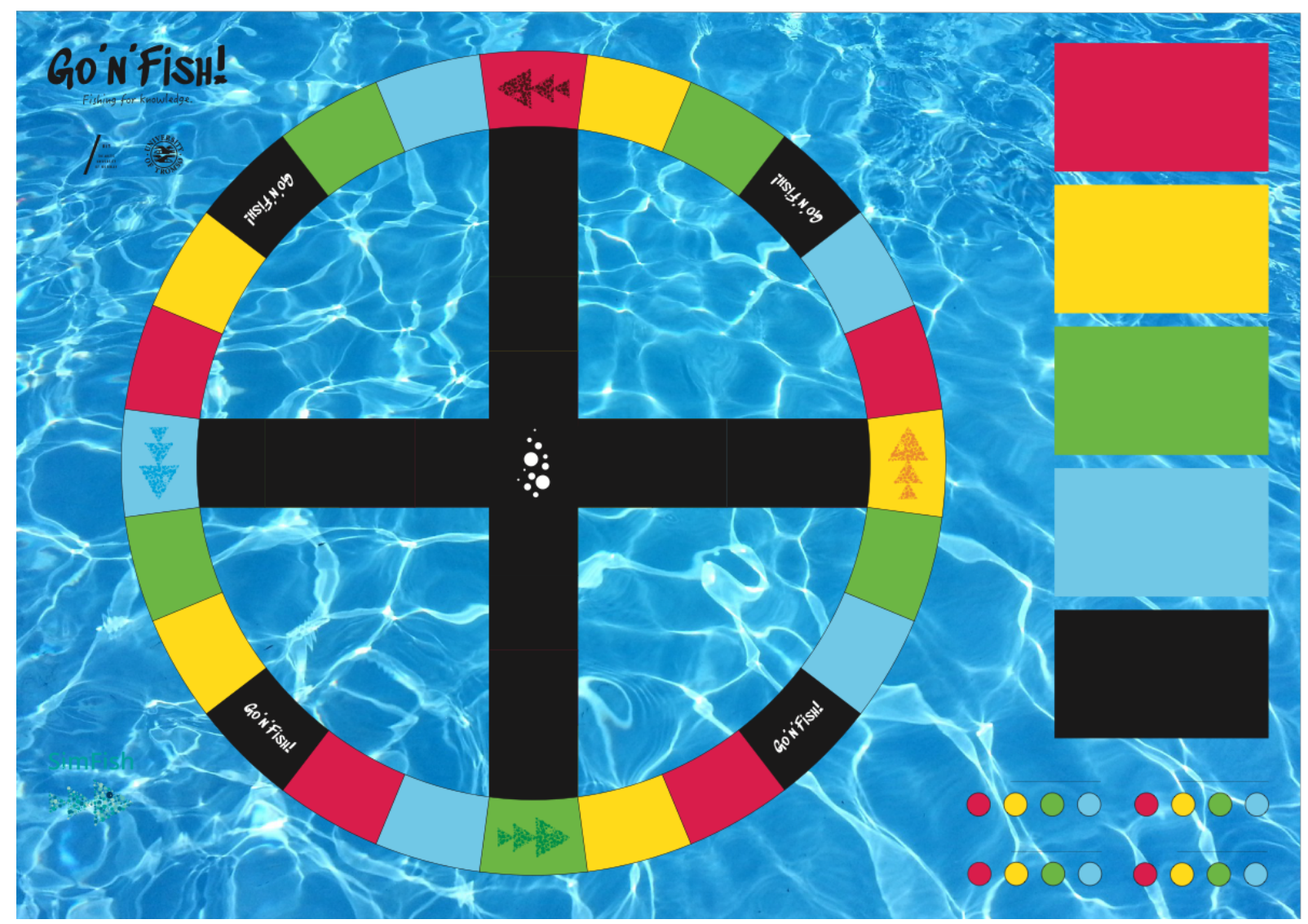

Figur 1: Go'n'Fish ${ }^{5}$

En vesentlig forskjell mellom Go'n'fish og spill som Trivial Pursuit og Bezzerwisser er at Go'n'fish ikke har faste spørsmål, men spørsmål som tilpasses emnet spillet anvendes i. Spillet kan således

\footnotetext{
5 Design by: Melania Borit, Margrethe Esaiassen, Petter Holm. Graphic design by: Ørjan Garfjell. Copyright @ 2017 SimFish. All rights reserved.simfish@uit.no
} 
betraktes som et fleksibelt multiverktøy for læring. Som spillbasert læring, består Go'n' fish av tre faser som beskrives nærmere i fortsettelsen.

\subsection{Første fase - studentene lager spørsmål}

Den første fasen i den spillbaserte læringen er at studentene lager spørsmålene til spillet. Lagringskapasiteten i vårt korttidsminne er svært begrenset (Miller, 1956). Dersom fagstoffet og informasjonen som formidles ved forelesninger skal føre til varige læringsresultater, må informasjonen bearbeides. Eksempler på bearbeiding er «summegrupper» og «spørretid» (Pettersen, 2005). Å lage spørsmål til et spill er et tredje eksempel. Når studentene går sammen i mindre grupper, drøfter hva som var sentralt i dagens undervisningsøkt og lager spørsmål til spillet, aktiveres tankearbeidet rundt fagstoffet. Informasjon bearbeides til abstrakte skjemaer, visuelle forestillinger eller språklige uttrykk som lagres permanent i langtidsminnet (Bjørndal, 2015). Spørsmålene studentene har laget samles inn, og emneleder velger ut spørsmål som omsettes til spillkort. Emneleder kan føye til egne spørsmål, for å sikre at sentrale deler av pensum dekkes. Hvert tema/kategori får sin farge på spillkortene. Spillkortene lages fortløpende i semesteret parallelt med at det er undervisning i temaene for hver av de fire forhåndsbestemte kategoriene i spillet. Studentene lager spillkortene også i den sorte kategorien. Denne kategorien er ikke relatert til det faglige innholdet i emnet, men bidrar til en sosialiserende dimensjon $\mathrm{i}$ gjennomføringen av spillingene. I denne kategorien får studentene oppgaver som relaterer til fremføringen av neste spillekort, eller lekende aktiviteter. Dette gir studentene muligheten til å praktisere forskjellige verbale aktiviteter og rutiner som inngår i sosiale sammenhenger, «Playful talking» (Lytra, 2015). Med dette begrepet favner Lytra om de mange nyansene som inngår i sosial samhandling: erting, spøk, humor, ordspill, parodiering, og musikalitet i kommunikasjon.

\subsection{Andre fase - spillseansen}

Den neste fasen er selve spillseansen. Under spillet er studentene to og to på lag, og det er tre eller fire lag i hvert spill. Studentene spiller spillet slik det er beskrevet ovenfor. En innvending mot bruk av spørrespill i undervisning er at det er en vanlig quiz i annen drakt, og at studentene er passive når det ikke er deres tur (Nicholson, 2011). Denne kritikken unngår dette spillet da det ikke eksisterer noe fasit i spillet. Det er motspillerne som avgjør om svaret er tilfredsstillende. Dette krever kontinuerlig refleksjon, argumentasjon og diskusjon både innad i laget som skal svare på spørsmålet og mellom spillerne på de øvrige lagene som skal avgjøre om svaret er tilfredsstillende. På denne måten er spillerne involvert hele tiden; når de lager spørsmål til spillet og når de spiller spillet i en spille-og-snakke-syklus enten i rollen som spiller eller dommer. I spillet tar studentene i bruk en læringsstrategi som omtales som «retrieval practice», hvor de anstrenger seg for å hente frem kunnskap de har tilegnet seg tidligere i semesteret heller enn å lese pensum på nytt. Studier av retrieval practice fra de siste tiårene viser at denne læringsstrategien kan ha sterkere effekt på langtidslæring enn repetisjon av pensum (Agarwal et al., 2012; Karpicke \& Grimaldi, 2012; Lun et al., 2018). Dette spillet er en læringsform som lar studentene praktisere denne studieteknikken, både når de svarer og når de er dommere overfor medstudentene. 


\subsection{Tredje fase - etterarbeid}

Ved å observere studenter som spiller spillet, kan foreleser få innsyn i hvilke deler av pensum studentene erfarer som vanskelig. Dette kan gi retning til hva som bør prioriteres i repetering og videre bearbeiding av kunnskap. På samme måte kan også studentene bli klar over hva de ikke kan når de spiller spillet, noe som kan gi føringer for prioriteringer i studentenes videre arbeid med pensum (Richland et al., 2009). Strukturert etterarbeid gjennomføres på ulike måter i de emnene hvor Go'n'fish som fleksibelt multiverktøy for læring er tatt i bruk. Ved lektorutdanninga blir de 14 spørsmålene fra hver kategori lagt ut på den digitale læringsplattformen. På denne måten kan spillets innhold være en strukturerende ressurs i arbeid med pensum og læringsmålene i emnet frem mot eksamen. På lektorutdanninga har studentene også mulighet til å låne spillet, dersom de ønsker å organisere egne kollokvier. Spillet gir således studentene muligheten til å bruke retrieval practice som studieteknikk utover spilløktene som er organisert av emneleder.

\subsection{Kunnskapsspillet og læringsmålene i pedagogikkemnet}

På lektorutdanninga reflekterer de fire kategoriene i spillet sentrale tema i læringsutbyttebeskrivelsen i pedagogikkemnet første semester: lcering og lceringsteorier (kategori rød), ungdom og identitet (kategori gul), danning (kategori grønn) og etiske teorier og profesjonsetikk (kategori blå). Dette er tema som omtales i Nasjonale retningslinjer for lektorutdanning for trinn 8-13 (Nasjonalt råd for lærerutdanning, 2017). ${ }^{6}$ Når det gjelder den siste kategorien står for eksempel følgende formulert: «Profesjonsfaget skal ivareta profesjonsetikk og bidra til å utdanne lektorer som har kunnskap om etikk og kan handle etisk forsvarlig.» (s. 12). Videre står det at utdanninga skal legge «...vekt på at studenten utvikler evne til etisk refleksjon, kreativitet, kritisk vurdering og problemløsning, kompetanser som skal bidra til å forberede dem for livslang læring.» (s. 4).

I hver kategori er det to typer spørsmål; teorispørsmål og refleksjonsspørsmål. Teorispørsmål krever at studentene definerer teoretiske begreper, mens refleksjonsspørsmål er spørsmål som skal stimulerer studentenes utvikling av evne til refleksjon, kritisk vurdering og problemløsning. Vi fortsetter med å bruke etikk-kategorien som eksempel. Et teorispørsmål i spillet er: «Redegjør for en etisk teori som har resultatet av en persons handling i fokus.» Eksempel på et refleksjonsspørsmål er: «Karl i 8. klasse synes synd på klassekompisen Arne som nesten aldri har med seg matpakke eller noe å drikke på skolen. Karl stjeler en yoghurt i kjøleskapet på skolen og gir denne til Arne. Hvordan synes du læreren skulle ha reagert dersom hun oppdaget dette? Ta i bruk ulike etiske teorier når du reflekterer over caset.» De to kategorier spørsmål i Kunnskapsspillet er ment å stimulere studentenes læringsutbytte både når det gjelder kunnskaper (teori) og ferdigheter (evne til refleksjoner).

\footnotetext{
${ }^{6}$ https://uit.no/utdanning/emner/emne/671159/pff-1020. De tre siste læringsutbyttene i emnet (å ta elevens perspektiv, klasseledelse og læringsmiljø og observasjon som metode) arbeider studentene med $\mathrm{i}$ en akademisk tekst som leveres inn etter praksis.
} 


\section{TEORETISK FORANKRING}

I motsetning til Piaget, som i sin kognitive læringsteori var opptatt av læring på det mentale planet hos den enkelte, forfektet Vygotskij $(1978,2001)$ en forståelse av læring som grunnleggende sosialt. I følge Vygotskij konstrueres kunnskap i sosialt samspill mellom individer, hvor individet kan strekke seg og forstå mer i samspill med andre som er mer kyndig. Vygotskij relaterer læring til hvordan mennesker tilegner seg og bruker materielle og kulturelle redskaper i en bestemt kontekst, for eksempel pedagogikkundervisningen på lektorutdanninga. Disse redskapene er der fra før, før individets inntreden i verden (Säljö, 2013). Språk er et eksempel på et kulturelt redskap. Ulike artefakter fremstilt av mennesket til et spesielt formål, for eksempel en terning, et spillbrett og spørrekort $\mathrm{i}$ et brettspill, er eksempler på materielle verktøy. Som beskrevet innledningsvis, argumenterte Bridge (2014) for velkjente spill som har lave oppstartskostnader. Læringen i slike spill, som for eksempel Kunnskapsspillet, handler ikke om å lære og beherske de materielle redskapene i spillet, men om å lære gjennom språksetting av kunnskap i emnet hvor spillet tas i bruk.

Krysningspunktet mellom sosiokulturell læringsteori og spillbasert læring er godt etablert i litteraturen. Plass et al. (2015) går grundig gjennom litteraturen som er fundamentet for spillbasert læring fra et sosiokulturelt læringperspektiv. De er spesielt opptatte av hvordan spill kan tilrettelegge for lekende laering, hvor det ikke er spillet i seg selv som er det viktigste, men at deltakerne utvikler en mental modell for hvordan informasjon henger sammen. Et viktig poeng med spillet i spillbasert læring er ikke bare muligheten til å oppnå suksess, men også å feile uten at det har store konsekvenser. Perspektivet med lekende læring (Plass et al. 2015), underbygger læringslyst og et trygt læringsmiljø som sentralt ved bruken av Kunnskapsspillet i undervisningen ved lektorutdanninga. Uavhengig av læringsteori, anses gode relasjoner og et godt læringsmiljø som vesentlig for læring. Med henvisning til Vygotskij (1978, 2001), synliggjør imidlertid Dysthe (2013) en vesentlig distinksjon. Der sosial samhandling og relasjoner anses som rammen rundt læring i enkelte læringsteorier, er sosial samhandling utgangspunktet for læring i sosiokulturell læringsteori.

\section{DATAMATERIALE OG METODE}

Datamaterialet som ligger til grunn for denne studien er $\mathrm{i}$ all hovedsak individuelle skriftlige studentevalueringer gjennomført ved bruk av nettskjema i kull 2017, 2018 og 2019. ${ }^{7}$ Datamaterialet består av kvantitative data innhentet gjennom spørsmål med lukkede svaralternativer og kvalitative tekstsvar innhentet gjennom åpne spørsmål i nettskjemaet. I tillegg inngår gruppeevalueringer fra studenter og data fra evalueringsmøter med eksterne sensorer.

For alle de tre kullene ble det stilt tre spørsmål som retter seg direkte mot studentenes erfaringer med Kunnskapsspillet. Det første spørsmålet omhandlet studentenes tilfredshet med å spille spillet: «Likte

\footnotetext{
${ }^{7}$ https://uit.no/om/orakelet/frag?p document id=516231
} 
du å spille Kunnskapsspillet?» Det andre spørsmålet omhandlet studentens vurdering av potensiell nytte frem mot eksamen: «Tror du Kunnskapsspillet vil være til nytte i dine forberedelser til eksamen?» Svaralternativene på disse to spørsmålene var «Ja i stor grad», «Ja litt» og «Nei». Det tredje spørsmålet var et åpent spørsmål hvor studentene kunne utdype med kommentarer om Kunnskapsspillet. Til sammen var det 90 studenter som skrev kommentarer. For Kull 2019, ble det lagt til to nye åpne spørsmål knyttet til bruken av Kunnskapsspillet. Det første var en oppfordring om å begrunne svaret knyttet til potensiell nytte frem mot eksamen. Av de 75 studentene som svarte på dette spørsmålet var det 25 studenter som også begrunnet svaret. Det neste spørsmålet rettet seg mot studentenes profesjonsutvikling: "Tror du at du vil ta i bruk spill som Kunnskapsspillet $\mathrm{i}$ undervisningen når du blir lektor?" Spørsmålet ble stilt uten lukkede svaralternativer. Av de 67 studentene som svarte på spørsmålet, var det 12 studenter som også begrunnet sitt svar. Til sammen består det kvalitativt materiale av 234 tekstsvar med varierende lengde fra ett til 51 ord.

Andre spørsmål i evalueringen som har relevans i denne studien er spørsmål om studentenes egeninnsats, samt trivsel og trygghet. Følgende to spørsmål ble stilt om studentenes egeninnsats: «Hvor tilfreds er du med din egen innstas i emnet?» «Hvor tilfreds er du med din egen innsats når det gjelder arbeid med pensumlitteraturen i emnet?» Svaralternativene på disse to spørsmålene var «Svært tilfreds», «Tilfreds» og «Mindre tilfreds». Alle kullene ble stilt følgende to spørsmål om trivsel og trygghet: «Dersom du skulle ha behov for det, har du medstudenter på lektorutdanninga som du kan snakke fortrolig med?» «Dersom du skulle ha behov for det, opplever du at det er ansatte på lektorutdanninga som du kan snakke fortrolig med?» Svaralternativene på disse to spørsmålene var «Ja», «Nei» og «Usikker».

\subsection{Utvalg}

I de tre kullene var det til sammen 328 studenter som bestod eksamen i emnet. Av disse var det 278 som deltok i den individuelle evalueringen. Studien er godkjent av Norsk senter for forskningsdata. Studentene ble bedt om å krysse av på evalueringsskjemaet om de aksepterte at evalueringen ble brukt i forskning. Til sammen var det 274 studenter som også samtykket til deltakelse i forskning (Tabell 1). 
Tabell 1. Oversikt studenter og antall deltakere i studien, kull 2017, 2018 og $2019^{8}$

\begin{tabular}{|c|c|c|c|c|c|}
\hline & $\begin{array}{c}\text { Semesterregistrert } \\
\text { og møtt til } \\
\text { undervisning }\end{array}$ & $\begin{array}{l}\text { Oppmeldt } \\
\text { til eksamen }\end{array}$ & $\begin{array}{c}\text { Bestod } \\
\text { eksamen }\end{array}$ & $\begin{array}{c}\text { Fylte ut } \\
\text { evalueringsskjema }\end{array}$ & $\begin{array}{c}\text { N: Samtykket til } \\
\text { deltakelse i } \\
\text { forskning }\end{array}$ \\
\hline $\begin{array}{l}\text { Kull } \\
2017\end{array}$ & 123 & 113 & 111 & 95 & 95 \\
\hline $\begin{array}{l}\text { Kull } \\
2018\end{array}$ & 135 & 124 & 124 & 107 & 105 \\
\hline $\begin{array}{l}\text { Kull } \\
2019\end{array}$ & 108 & 102 & 93 & 76 & 74 \\
\hline Sum & 366 & 339 & 328 & 278 & 274 \\
\hline
\end{tabular}

\subsection{Analyseprosessen}

Alle tre forfattere har deltatt i analyse av data. Det kvantitative materialet innsamlet gjennom spørsmål med lukkede svaralternativer, er analysert gjennom frekvensanalyser. Det kvalitative materialet er analysert både gjennom kategoriseringer og deretter kvantifisering av studentenes svar, og gjennom temasentrerte kvalitative analyser (Thagaard, 2013). For eksempel har vi i analyse av andre kommentarer om Kunnskapsspillet laget de tre kategoriene positive ytringer, kritiske merknader og usikker, og talt opp hvor mange ytringer det var i hver kategori (Tabell 4). I kvantifiseringen av studentenes vurdering av spillets relevans i egen undervisning som fremtidige lektorer har vi kategorisert studentenes svar i følgende tre kategorier: ja, kanskje/sannsynlig og nei (Tabell 5).

I de temasentrerte kvalitative analysene har vi sett nærmere på kvaliteter studentene erfarer gjennom bruk av kunnskapsspillet. Av de 234 tekstsvarene, er det 127 svar hvor ulike kvaliteter studentene erfarer lar seg analysere frem. De kvalitative analysene kan betegnes som en abduktiv analyseprosess, altså en veksling mellom fortolkning drevet av empirien og teoribasert begrepsfesting. Järvinen og Mik-Meyer (2017) beskriver dette som en form for dialog mellom teori og data.

\section{MULIGE STYRKER OG SVAKHETER VED STUDIEN}

Nytteverdien og bruk av studentevalueringer i kvalitetsforbedrende arbeid i høyere utdanning diskuteres (Esarey \& Valdes, 2020; Wang, \& Williamson, 2020). Dette er diskusjoner som er relevante også i vurdering av studentevalueringer som datamateriale i forskning. Blant annet problematiseres

\footnotetext{
8 Kilde: Felles Studentsystem: Rapport 101.006 Søkerliste - ja/Svar/Møtt/Reservert og Rapport 580.001 Resultatfordeling vurderingsenhet
} 
sammenhengen mellom gode studentevalueringer og studentenes læringsutbytte. Uttl et al. (2017) finner i sin metaanalyse ikke noen sammenheng mellom studenters tilfredshet med underviseren og undervisningen, og studentenes læring. Vi undersøker imidlertid ikke effekten underviseren eller undervisningen kan ha på studentenes læring. Det er studentenes tilfredshet med spillet, opplevelse av nytte frem mot eksamen og opplevelse av profesjonsrelevans som studeres. Forventninger om mestring er en innflytelsesrik faktor i studentenes læringsarbeid, noe Bandura (1997) begrepsfester som selfefficacy. Studentene har prestert godt på pedagogikkemnet første semester, dette kan ha påvirket studentevalueringene, men det kan også ha vært en forsterker i studentenes arbeid i studiet. En tredje innvending rettes mot bruk av standardiserte spørsmål i studentevalueringer (Spooren, et al., 2013). Sentralt i vårt evalueringsdesign er fritekstsvar hvor studentene kan gi mer utfyllende informasjon.

Første- og tredjeforfatter har hatt roller i utviklingen av spillet som denne studien retter fokus mot. Eksterne sensorer, som jobber både i ungdomsskole, videregående skole og ved andre lærerutdanningsinstitusjoner, har deltatt på evalueringsmøter og uttalt seg om sine vurderinger av studentenes læringsutbytte. Sensorer har hatt tilgang til de 56 spørsmålene fra de fire kategoriene i sine forberedelser til eksamen og har gitt god respons på hvordan dette har bidratt i struktureringen av både egen og studentenes forberedelse frem mot eksamen. Vi anser dette som viktig i kvalitetssikringen av artikkelens bidrag.

\section{RESULTATER}

Resultatene viser at studentene opplevde spillet som nyttig i forberedelsene til eksamen, de likte å spille Kunnskapsspillet, og de fleste ser for seg at de vil ta i bruk lignende spill i rollen som fremtidige lektorer. Når det gjelder studentenes vurdering av egen innsats i emnet viser resultatene at de fleste var tilfredse med egen innsats, mens under halvparten var tilfredse med eget arbeid med pensum. Angående trivsel og trygghet, viser resultatene at flertallet av studentene i de tre kullene har medstudenter og ansatte de kan snakke fortrolig med dersom de har behov for det. Disse resultatene utdypes nærmere.

\subsection{Studentene opplever spillet som nyttig i eksamensforberedelsene}

Studentene fylte ut evalueringsskjemaet før eksamen. I gjennomsnitt mente $74 \%$ av studentene i de tre kullene at spillet «i stor grad» ville være til nytte i forberedelsene frem mot eksamen (Tabell 2). Bare 3 $\%$ av studenter svarte «nei» på dette spørsmålet. De eksterne sensorer mente at studentene jevnt over hadde kommet langt i sin profesjonsutvikling, til tross for at de bare har vært lektorstudenter i fire måneder ved eksamenstidspunktet. Det er liten forskjell mellom de tre kullene, men studentene i kull 2017 ser i noe større grad en potensiell nytte. Hele $81 \%$ av studentene i dette kullet mente spillet i stor grad ville være til nytte frem mot eksamen, mot tilsvarende $66 \%$ i kull 2018 og 77 \% i kull 2019. Disse forskjellene kan knyttes til at kull 2017 ble bedre kjent med spillet, da de spilte det to ganger før eksamen. 
Tabell 2: Nytte frem mot eksamen

\begin{tabular}{|l|l|l|l|l|}
\hline \multicolumn{5}{|l|}{ Tror du Kunnskapsspillet vil være til nytte i dine forberedelser til eksamen? } \\
\hline & Antall svar & Ja i stor grad & Ja litt & Nei \\
\hline Kull 2017 & 88 & $71(81 \%)$ & $16(18 \%)$ & $1(1 \%)$ \\
\hline Kull 2018 & 105 & $69(66 \%)$ & $33(31 \%)$ & $3(3 \%)$ \\
\hline Kull 2019 & 75 & $58(77 \%)$ & $14(19 \%)$ & $3(4 \%)$ \\
\hline Kullene samlet & 268 & $198(74 \%)$ & $63(24 \%)$ & $7(3 \%)$ \\
\hline
\end{tabular}

\subsection{Studentene likte å spille spillet}

Studentene gir i evalueringen uttrykk for at de likte å spille Kunnskapsspillet (Tabell 3). I gjennomsnitt likte $65 \%$ av studentene i de tre kullene det «i stor grad». Til sammen var det bare 4 studenter i de tre kullene som svarte «nei» på dette spørsmålet, mens $33 \%$ likte det litt.

Tabell 3: Tilfredshet med å spille Kunnskapsspillet

\begin{tabular}{|l|l|l|l|l|}
\hline \multicolumn{2}{|l|}{ Likte du å spille Kunnskapsspillet? } \\
\hline & Antall svar & Ja i stor grad & Ja litt & Nei \\
\hline Kull 2017 & 81 & $54(67 \%)$ & $26(32 \%)$ & $1(1 \%)$ \\
\hline Kull 2018 & 105 & $67(64 \%)$ & $36(34 \%)$ & $2(2 \%)$ \\
\hline Kull 2019 & 74 & $47(64 \%)$ & $26(35 \%)$ & $1(1 \%)$ \\
\hline Kullene samlet & 260 & $168(65 \%)$ & $88(33 \%)$ & $4(2 \%)$ \\
\hline
\end{tabular}

Studentenes kommentarer om Kunnskapsspillet underbygger resultatene om tilfredshet presentert i Tabell 3. Til sammen 90 studenter svarte på dette åpne spørsmålet, fordelt på i underkant av halvparten av kull 2017, rundt en femtedel av kull 2018 og en tredjedel av kull 2019. Det er stor overvekt av positive ytringer i studentenes fritekstsvar (80\%), hvor kull 2017 prosentvis har flest positive ytringer (Tabell 4). Kull 2019 er det kullet hvor flest studentene har kritiske merknader og flest forslag til hva som kunne forbedret bruken av Kunnskapsspillet: 33 \% i kull 2019 sammenlignet med $10 \%$ i kull 2018 og $12 \%$ i kull 2017. En forklaring på dette kan være at emneleder for kull 2019 var nytilsatt. Å introdusere og gjennomføre spillet var sannsynligvis mer utfordrende for vedkommende, enn for emneleder for kull 2017 og 2018 som hadde utviklet Kunnskapsspillet. 
Tabell 4: Kommentarer i fritekst om Kunnskapsspillet

\begin{tabular}{|l|l|l|l|l|}
\hline & $\begin{array}{l}\text { Antall } \\
\text { kommentarer }\end{array}$ & $\begin{array}{l}\text { Positive } \\
\text { ytringer }\end{array}$ & $\begin{array}{l}\text { Kritiske merknader/ } \\
\text { forslag til endringer }\end{array}$ & Usikker \\
\hline Kull 2017 & $43(45 \%)$ & $38(88 \%)$ & $5(12 \%)$ & $2(10 \%)$ \\
\hline Kull 2018 & $20(19 \%)$ & $16(80 \%)$ & $2(10 \%)$ & \\
\hline Kull 2019 & $27(36 \%)$ & $18(67 \%)$ & $9(33 \%)$ & $2(2 \%)$ \\
\hline Kullene samlet & $90(\mathrm{x} \%)$ & $72(80 \%)$ & $16(18 \%)$ & \\
\hline
\end{tabular}

\subsection{Spillet oppleves relevant som fremtidige lektorer}

I evalueringen ble kull 2019 stilt spørsmålet om de tror de vil ta i bruk Kunnskapsspillet eller lignende spill i egen undervisning som fremtidig lektor. Av de 74 studentene som deltok i studien i dette kullet, var det 67 (90 \%) som svarte også på dette spørsmålet. Resultatene viser at de fleste, 66 \%, tenker at de selv vil ta det i bruk (Tabell 5). Formuleringer de bruker er; «ja», «absolutt», definitivt» og «helt klart». I tillegg er det $30 \%$ som tenker at de kanskje eller sannsynligvis vil ta spillet i bruk. Disse studentene bruker formuleringer som; «vil tro det», «muligens», «kanskje», «sannsynligvis», «kan fort hende», «kan være en god idè» og «ikke umulig». De resterende (4 \%) svarer «nei» på dette spørsmålet.

Tabell 5: Studentenes vurdering av spillets relevans i egen undervisning som fremtidig lektor

\begin{tabular}{|l|l|l|l|}
\hline \multicolumn{3}{|l|}{ Tror du at du kan ta i bruk spill som Kunnskapsspillet i undervisning når du blir lektor? } \\
\hline Antall svar & Ja & Kanskje/Sannsynligvis & Nei \\
\hline $67(90 \%)$ & $44(66 \%)$ & $20(30 \%)$ & $3(4 \%)$ \\
\hline
\end{tabular}

\subsection{Tilfredse med egen arbeidsinnsats og noe mindre tilfredse med arbeid med pensum}

Som det fremgår av tabell 6 er tre fjerdedeler tilfredse med egen innsats i pedagogikkemnet første semester. I overkant av $10 \%$ er svært tilfredse, og tilsvarende andel er mindre tilfredse. Resultatene viser videre at $\mathrm{i}$ underkant av halvparten er tilfredse og omtrent like mange er mindre tilfredse når det gjelder arbeid med pensum (tabell 7). Mindre enn $10 \%$ er svært tilfredse med eget arbeid med pensum. 
Tabell 6: Tilfredshet med egen arbeidsinnsats

\begin{tabular}{|l|l|l|l|l|}
\hline \multicolumn{5}{|c|}{ Hvor tilfreds er du med din egen innsats i pedagogikk første semester? } \\
\hline & Antall svar & Svært tilfreds & Tilfreds & Mindre tilfreds \\
\hline Kull 2017 & 94 & $11(12 \%)$ & $71(75 \%)$ & $12(13 \%)$ \\
\hline Kull 2018 & 104 & $16(15 \%)$ & $75(72 \%)$ & $13(13 \%)$ \\
\hline Kull 2019 & 77 & $9(12 \%)$ & $59(77 \%)$ & $9(11 \%)$ \\
\hline Kullene samlet & 275 & $36(13 \%)$ & $205(75 \%)$ & $34(12 \%)$ \\
\hline
\end{tabular}

Tabell 7: Tilfredshet med eget arbeid med pensum

\begin{tabular}{|l|l|l|l|l|}
\hline \multicolumn{4}{|c|}{ Hvor tilfreds er du med din egen innsats når det gjelder arbeid med pensum i emnet? } \\
\hline & Antall svar & Svært tilfreds & Tilfreds & Mindre tilfreds \\
\hline Kull 2017 & 94 & $9(10 \%)$ & $47(50 \%)$ & $38(40 \%)$ \\
\hline Kull 2018 & 107 & $10(9 \%)$ & $49(46 \%)$ & $48(45 \%)$ \\
\hline Kull 2019 & 74 & $3(4 \%)$ & $33(45 \%)$ & $38(51 \%)$ \\
\hline Kullene samlet & 275 & $322(8 \%)$ & $205(47 \%)$ & $124(45 \%)$ \\
\hline
\end{tabular}

\subsection{Studentenes trivsel og trygghet er styrket etter endring av pedagogikkemnet høsten 2017}

Evalueringer gjennomført et halvt år etter studiestart for kull 2016, viste at $41 \%$ av studentene opplevde å ha en medstudent og 40 \% opplevde å ha en faglig ansatt de kunne snakke fortrolig med ved behov. ${ }^{9}$ Resultatene viser en markant styrking av studentenes trivsel og trygghet for kull 2017, 2018 og 2019, da dette økte til henholdsvis gjennomsnittlig $81 \%$ (tabell 8) og $70 \%$ (tabell 9). Som nevnt innledningsvis ble en rekke kvalitetsforbedrende tiltak satt inn fra og med kull 2017. Resultatene kan ikke tilskrives innføring av spillbasert læring alene. Jamfør Plass et al. (2015) bidrar imidlertid spillbasert læring til at studentene kan bli kjent under en lekende samarbeidsform, noe som kan bidra til nettopp trivsel, trygghet og styrket kullfølelse.

\footnotetext{
${ }^{99}$ Evalueringsdesignet ble endret i 2017 med nye spørsmål og fokus. Disse to spørsmålene om trivsel og trygghet ble imidlertid stilt både $f \varnothing r$ og etter revideringen av pedagogikkement første semester.
} 
Tabell 8: En medstudent på utdanninga å snakke fortrolig med

\begin{tabular}{|l|l|l|l|l|}
\hline \multicolumn{5}{|c|}{ Dersom du har behov for det, har du medstudenter du kan snakke fortrolig med? } \\
\hline & Antall svar & Ja & Usikker & Nei \\
\hline Kull 2017 & 94 & $77(82 \%)$ & $9(10 \%)$ & $8(8 \%)$ \\
\hline Kull 2018 & 107 & $81(76 \%)$ & $13(12 \%)$ & $13(12 \%)$ \\
\hline Kull 2019 & 76 & $67(88 \%)$ & $3(4 \%)$ & $6(8 \%)$ \\
\hline Kullene samlet & 277 & $225(81 \%)$ & $25(9 \%)$ & $27(10 \%)$ \\
\hline
\end{tabular}

Tabell 9: En ansatt på utdanninga å snakke fortrolig med

\begin{tabular}{|c|c|c|c|c|}
\hline \multicolumn{5}{|c|}{$\begin{array}{l}\text { Dersom du har behov for det, opplever du at det er } \\
\text { kan snakke fortrolig med? }\end{array}$} \\
\hline & Antall svar & $\mathrm{Ja}$ & Usikker & Nei \\
\hline Kull 2017 & 93 & $71(76 \%)$ & $19(20 \%)$ & $3(4 \%)$ \\
\hline Kull 2018 & 110 & $81(74 \%)$ & $16(14 \%)$ & $13(12 \%)$ \\
\hline Kull 2019 & 76 & $44(58 \%)$ & $26(34 \%)$ & $6(8 \%)$ \\
\hline Kullene samlet & 279 & $196(70 \%)$ & $61(22 \%)$ & $22(8 \%)$ \\
\hline
\end{tabular}

\section{DISKUSJON AV KVALITET VED BRUK AV KUNNSKAPSSPILLET}

Gjennom analyse av 127 fritekstsvar, har vi fătt et dypere innblikk i studentenes erfaringer og refleksjoner knyttet til bruk av Kunnskapsspillet. Fritekstsvarene er interessante fordi de viser nyanser og begrunnelser for hva studentene opplever som positivt og hvilke kritiske merknader og forslag de har til endringer. De fleste var svært fornøyde. Et lite mindretall var kritiske. Materialet viser ytterpunkter i studentenes tilfredshet. En student som var svært fornøyd skriver: «Veldig artig. Det var som ludo, monopol og alias i et spill med stoff som var pensum, 10 av 10 for fun.» Motsatsen er denne studenten: «Det finnes bedre måter å gjennomgå spørsmål på. For eksempel at man går gjennom spørsmål i plenum i fellesundervisningen.» Studentene hadde også ulike meninger om den svarte kategorien. En av dem skriver: «Det var bra før de svarte - så ble det bare enda bedre». En annen skriver: «Tullespørsmål var unødvendige. Burde vært erstattet med en vanlig kategori.»

De forskjellige temaene som trer frem i studentene fritekstsvar kan knyttes til det vi kaller kvalitetsdimensjoner ved Kunnskapsspillet. Gjennom den abduktive analyseprosessen har tre kvalitetsdimensjoner utkrystalisert seg: læringsutbytte, meningsfull sammenheng, og læringslyst, trivsel og trygghet (Figur 2). De tre kvalitetsdimensjonene henger sammen, kan være gjensidig avhengig av hverandre og også overlappende. Enkelte studenter trekker frem alle de tre kvalitetsdimensjonene. Dette 
fremkommer blant annet i denne studentens kommentar: «En artig, sosial og smart måte å oppsummere pensum på hvor jeg fikk høre andres syn på spørsmålene.» Studenten legger både vekt på læringslyst (det var artig og sosialt), læringsutbytte (det var nyttig å høre medstudentenes svar) og meningsfull sammenheng (det var en smart måte å oppsummere pensum på). I fortsettelsen gir vi eksempler fra studentenes fritekstsvar innen hver av de tre kvalitetsdimensjonene og relaterer til sosiokulturell læringsteori og teori om spillbasert læring. Deretter synliggjør vi hvordan de tre kvalitetsdimensjonene henger sammen i en diskusjon av Kunnskapsspillets profesjonsrelevans.

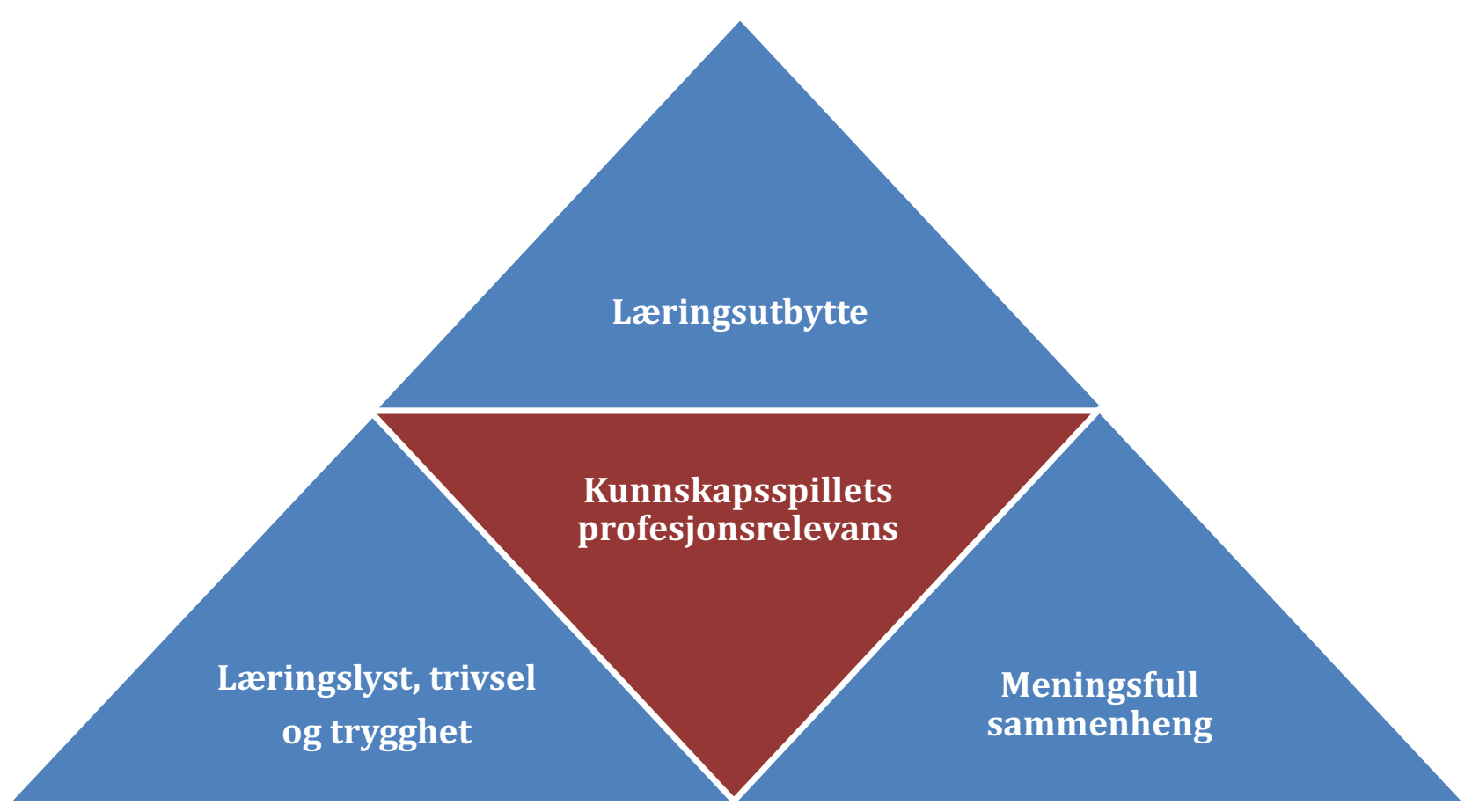

Figur 2: Kvalitetsdimensjoner i studentenes evaluering av Kunnskapsspillet

\subsection{Læringsutbytte}

Læringsutbytte forstås på ulike måter i nasjonal og internasjonal forskning. Begrepet retter seg for det første mot intensjonen, altså hva studentene forventes å kunne etter endt emne/utdanning. For det andre anvendes begrepet om resultatet, altså hva studenten faktisk sitter igjen med (Prøitz, 2016). I vår studie knyttes læringsutbytte til studentenes forventninger, noe som kan relateres til begrepet om self-efficacy (Bandura, 1997). Studentene opplever førstesemesteremnet i pedagogikk som et stort og omfattende emne hvor det er mye å lese. Flertallet mener at Kunnskapsspillet vil være til nytte frem mot eksamen og bidra til et godt læringsutbytte. Studentene begrunner dette på ulike måter. Enkelte er instrumentelle: «Kunnskapsspillet er jo eksamensspørsmålene. Så det vil åpenbart være nyttig.» Andre trekker frem at spillet er til hjelp fordi det avdekker kunnskapshull. En student skriver: «Noen spørsmål var vanskelige, men det er en fin måte å få en pekepinn på hva man må lese mer på.» En annen skriver: «Når man ser på spørsmålene leser man litt annerledes og vet hva som er viktig i et hav av informasjon.» En tredje student skriver: «Ikke bare lærer man ting og kan vise det man kan, men det blir svært åpenbart at det er områder man har svært lite kunnskap om.» Disse kommentarene synliggjør at studentene opplever at Kunnskapsspillet bidrar til samstemt undervisning (Constructive alignment), altså samsvar mellom 
læringsmål, læringsaktiviteter og eksamensform (Biggs \& Tang, 2011), og dette motiverer studentene. Kirk-Johnson et al. (2019) peker på at anstrengende læringsformer gir mer effektiv langtidslæring («desirable difficulties»), men viser i sine studier at studenter ofte velger bort effektive læringsstrategier fordi de feiltolker anstrengelse som et tegn på at de ikke får det til. Studentenes kommentarer peker på at Kunnskapsspillet hjelper studentene å strukturere arbeidet med pensum uten å demotivere dem. For enkelte bidro dette til å ta ned stressnivået frem mot eksamen. En student mener at Kunnskapsspillet var en «av de ryddigste måtene å presentere eksamensrelevant pensum på i et så omfattende fag.» En annen skriver: «Her har jeg faktisk mulighet til å få en titt inn i hva jeg burde lese på til eksamen, hva forberede meg på. Føles tryggere, mindre stressende.»

Flere studenter legger vekt på kvaliteten i det å samarbeide med andre og trekker frem at dette bidro til eget læringsutbytte. En student skriver: «Greit å få en idé om hvor jeg er faglig, og få hjelp av medstudenter.» En annen student trekker frem at Kunnskapsspillet bidro i språksetting av egen læring: «...det er en artig måte å sette ord på teori sammen med andre og utfordre seg på faglige områder man kanskje er litt usikker på.» Et tredje eksempel er studenten som skriver: «Trodde ikke det skulle fungere og at det ikke var noe gøy, men det var veldig interessant. Jeg klarte å hente opp mye kunnskap jeg trodde jeg ikke kom til å få frem.» Studentene lærer av å søke hjelp når de selv har behov for det, og erfarer at de selv lærer av å forklare fagstoff for sine medstudenter, noe som kan forstås i lys av Vygotskijs teori om den proksimale utviklingssone. Med den proksimale utviklingssone, sikter Vygotskij til sonen som eksisterer mellom hva studentene kan på egen hånd, og det studenten er i stand til å lære gjennom støtte fra andre. Den/de andre som forstår mer fungerer som stillas, noe Vygotskij (2001) begrepsfester som scaffolding. Clapper (2015) kobler dette til samarbeidsbasert læring (cooperative-based learning), og viser hvordan bruk av spill kan bidra til å skape en sone hvor studentene kan bistå hverandre i å konstruere forståelse av pensum sammen.

\subsection{Læringslyst, trivsel og trygghet}

Den neste kvalitetsdimensjonen er laeringslyst, trivsel og trygghet. Begrepet læringslyst kan sies å stå i kontrast til begrepet læringstrykk som kom med PISA-undersøkelsene på begynnelsen av 2000-tallet. Der læringstrykk karakteriseres av ytre motivasjon, målstyring og mer kontroll (Ryan \& Deci, 2000), er studentens indre motivasjon og lyst til å lære i sentrum i læringslyst (Skaalvik \& Skaalvik, 2014). Motivasjon er et sentralt tema i forskning på spillbasert læring, og det er flere tilnærminger til hvordan motivasjonsfaktorer kan skreddersys i forskjellige læringsspill (Plass et al., 2015). Hovedinntrykket fra analyse av fritekstsvarene er at de aller fleste opplevde bruken av Kunnskapsspillet som engasjerende og motiverende i egen læring. En av studentene trekker frem at det var positivt å velge hvem de skulle spille sammen med og at spillet motiverte til å lese videre: «Jeg synes det er positivt at vi får mulighet til å låne spillet så man kan lese mer senere. Likte også at vi kunne velge gruppene slik at vi kunne være sammen med noen som vi trivdes og føler oss komfortable med.» Studentene trekker frem momenter som kan ses i lys av resultatene som viser at studentenes trivsel og trygghet er styrket etter endring av blant annet undervisningsmetoder med innføring av spillbasert læring. 
Mange av studentene vektla de sosiale aspektene ved bruk av Kunnskapsspillet, og det å kombinere spill og eksamensforberedelser sammen med medstudenter. Biggs (2003) skriver om læring utenfor den tradisjonelle forelesningssituasjonen og fremhever interaksjon i grupper. Bruk av Kunnskapsspillet stimulerte arbeidet i studentdrevet kollokvieaktivitet. I Kull 2017 var halvparten av spillene utlånt før eksamen. Ei kollokviegruppe som lånte Kunnskapsspillet skulle tilbringe helga sammen og bake pepperkaker og spille spillet. Studentene lånte også spillet på egen hånd. En student skriver: «Tenker å låne det med meg og skrive ned spørsmålene så jeg kan øve på bussen.» En annen, sterkt konkurransedrevet student, lånte spillet for å forberede seg før hun skulle spille spillet i kollokviegruppa. Omkring halvparten av studentene i Kull 2017 møtte også på ikke-obligatorisk eksamensseminar tidlig på morgenen dagen etter studentenes julefest. Emneleder har også mottatt mange pensumrelaterte spørsmål på e-post relatert til de ulike kategoriene i Kunnskapsspillet. Studentenes bruk av Kunnskapsspillet i forberedelser til eksamen støtter på denne måten opp under den tidligere nevnte studieteknikken retrieval practice.

\subsection{Meningsfull sammenheng}

Meningsfull sammenheng, den tredje kvalitetsdimensjonen, er nært beslektet med koherens og samstemt undervisning. Koherens sikter mot hvordan integreringen av de ulike delene av lærerutdanninga (fordypning i fag, fagdidaktikk, pedagogikk og praksis) kan styrkes, og hvordan relevansen kan økes for å styrke studentenes profesjonskvalifisering (Hammerness, 2012; Heggen \& Raaen, 2014). Biggs (2003) skriver om forholdet mellom læring som en aktiv prosess hos studenten og relevante læringsaktiviteter, og fremhever betydningen av at studenten opplever og skaper mening i sin læringsprosess: "...meaning is not something imported or transmitted from teacher to learner, but something learners have to create for themselves. Teaching is simply a catalyst for learning." I følge Biggs er det altså studenten selv som må skape meningsfulle sammenhenger. Undervisning kan kun fungere som en katalysator for dette.

Samstemt undervisning handler som nevnt over om samsvar mellom læringsmål, læringsaktiviteter og eksamensform (Biggs \& Tang, 2011). Studentene uttrykker at de opplever meningsfull sammenheng mellom arbeidsform og eksamen. En student skriver: «Genialt spesielt med tanke på at svarene skal gis muntlig, som på eksamen, og at det ikke skal svares skriftlig.» Kunnskapsspillet bidrar videre til meningsfull sammenheng ved at de teoretiske spørsmålene og refleksjonsspørsmålene i de fire kunnskapskategoriene i Kunnskapsspillet samsvarer med læringsutbyttebeskrivelsesn i emnet når det gjelder både kunnskap (teori) og ferdigheter (evne til refleksjon). I relasjon til retrieval practice er kombinasjonen av teorispørsmål og refleksjonsspørsmål effektiv for å styrke langtidslæringen i begge kategorier (Agarwal, 2019).

\section{DISKUSJON AV KUNNSKAPSSPILLETS PROFESJONSRELEVANS}

De tre kvalitetsdimensjonene kan alle relateres til Kunnskapsspillets profesjonsrelevans. I fortsettelsen diskuteres utvikling av profesjonelt skjønn og identitet som fagperson, utvikling av endrings- og 
samhandlingskompetanse og kunnskapsspillet som modellering av undervisning som sentrale elementer i studentenes profesjonsutvikling.

\subsection{Utvikling av profesjonelt skjønn og identitet som lektor}

Askling et al. (2015) diskuterer hvordan man kan arbeide med utvikling av profesjonelt skjønn i lærerutdanningen. Lærere står stadig overfor nye situasjoner som innebærer etiske utfordringer og dilemma hvor det ikke finnes fasitsvar, og der løsninger må baseres på skjønn. Å diskutere etiske dilemma som lektorstudent er en forberedelse til håndtering av profesjonsetiske dilemma som fremtidige lektorer. Første semester på lektorutdanninga løftes dette frem i forberedelse til praksis og i pedagogikkundervisningen blant annet i den spillbaserte læringa. Blanchard og Buchs (2015) presenterer resultater fra en spørreundersøkelse om bruk av rollespill for å tydeliggjøre hvordan komplekse tema knyttet til bærekraft henger sammen. Et sentralt poeng for Blanchard og Buchs (2015) er at gjennom å spille rollespill fikk studentene dybdekunnskap om flere deler av et sammensatt tema, noe som gjorde det lettere å forstå helheten. Dette resultatet er relevant i vår sammenheng. Flere av studentene trekker frem at Kunnskapsspillet bidro til det de begrepsfester som «dybdekunnskap» og at det ble lettere å se sammenheng mellom ulike temaer. En student skriver: «Veldig fin måte å øve på, får reflektert rundt alle temaene.» En annen student trekker frem følgende: «Diskusjoner og avgrense hva som er mest relevant, og øvelse på hvordan man kan knytte sammen temaer gjennom oppgaveskriving.» Kvalifisering til læreryrket forutsetter ei utdanning som legger til rette for refleksjon, og hvor studentene kan «...lære av sine feil, tenkje kritisk, evne å spørje om råd og hjelp, være eksperimentell, evne å dele kunnskap med andre, være kollegaorientert og engasjert i utviklinga av lærerrolla.» (Heggen \& Raaen, 2014) Kunnskapsspillet gir studentene en ramme for diskusjon av faglige problemstillinger med medstudenter. Dette inngår som en del av studentenes konstruksjon av identiteten som fagperson. Gjennom interaksjonen med andre får de reflektere over komplekse profesjonsrelevante problemstillinger i en trygg setting hvor det ikke er farlig å ikke vite, eller ta feil. At så godt som alle likte å spille spillet, at spillet oppleves som nyttig i eksamensforberedelse og profesjonsrelevant, viser at Kunnskapsspillet gir ei god ramme for utprøving av profesjonelt skjønn, noe som er sentralt i utvikling av identitet som lektor.

\subsection{Utvikling av endrings- og samhandlingskompetanse}

Dagens lærere skal fungere i en skole i endring. Endringskompetanse, og kompetanse i samhandling med andre er helt sentralt for fremtidens lærer. I Kunnskapsspillet trer studentene inn i lærerrollen og får trent seg på å samhandle og ta ansvar i alle spillets faser. Evalueringen viser at de aller fleste tar læringsprosessen på alvor, selv om spillet også gir rom for humor og latter. Kun en av studentkommentarene peker på den motsatte erfaringen: «Det er en grei tanke og et godt virkemiddel, men for å få utbytte er man avhengig av å spille med andre som er like interessert som en selv - ellers risikerer man mye tull.» Det kan tenkes at tullet som studenten her viser til, kommer som et resultat av den sorte uhøytidelige kategorien. I all hovedsak virker det imidlertid som at den sorte kategorien oppleves som positiv av studentene og for studentenes læring, jamfør perspektivet med lekende læring 
(Plass et al., 2015). De sorte spillkortene kan også sies å ha profesjonsrelevans i studentenes utvikling av samhandlingskompetanse. I denne kategorien får studentene praktisere forskjellige former for verbale aktiviteter som inngår i sosial samhandling, i det Lytra (2015) omtaler som «Playful Talking». Dette er kommunikasjonsferdigheter lærere trenger i interaksjon med både elever og kollegaer. Det kan imidlertid være vanskelig å legge til rette for utvikling av slike ferdigheter i ei lektorutdanning.

Ved å spille Kunnskapsspillet har studentene erfart at de trenger hverandre og de kan nyttiggjør seg hverandres kompetanse i utvikling av egen kompetanse. Dette er en profesjonsrelevant erfaring. Forskning viser at undervisningen i norske klasserom er blitt mer individualisert etter Kunnskapsløftet (Haug, 2013). Sett i lys av NOU 2015: 8 Fremtidens skole (Kunnskapsdepartementet, 2015), er dette et paradoks. Ett av fire kompetanseområder som anbefales i fornyelse av skolens innhold er kompetanse i å kommunisere, samhandle og delta (s. 8). I følge Dysthe (2013) vil studenter stå bedre rustet i rollen som fremtidig lærer, dersom studenten er bevisst på selv å praktisere dialogiske og samspillsorienterte læreprosesser som student.

\subsection{Kunnskapsspillet som modellering av undervisning}

Ett av spørsmålene $\mathrm{i}$ evalueringen har direkte relevans for å undersøke Kunnskapsspillets profesjonsrelevans, nemlig spørsmålet om studentene vil ta Kunnskapsspillet eller lignende spill i bruk i egen undervisning som fremtidige lektorer. Så godt som alle mener at de absolutt eller muligens vil gjøre det. Studentene begrunner dette med at spillet oppleves som «relevant» og at det stimulerer læring ved å være «engasjerende», «morsomt», «motiverende» og at det «bringer inn variasjon $\mathrm{i}$ undervisninga». En av studenten skrev følgende: «...å ha noe konkret på jobbe med er ofte nyttig. I tillegg kan konkurranseinstinktet være til stor hjelp for å motivere elevene.» Å konkurrere kan engasjere. Det er mulig å vinne. Og som Plass et al. (2015) påpeker, det er også mulig å feile uten at det får store konsekvenser. En student skriver: «Slike måter er svært fine læringsmuligheter. Jeg selv er praktiker og lærer bedre av å diskutere enn å lese.» En av studentene som skal bli lektor i matematikk skriver: «Hadde ikke tenkt spesifikt på det (å ta spillet i bruk), men hvorfor ikke. Det er ikke nok muntlig aktivitet i matematikk så det kunne være et godt alternativ.»

Kunnskapsspillet har med andre ord fungert som noe mer enn at studentene har lært pedagogisk teori. For flere av studentene har det også modellert undervisning. Profesjonsrelevansen for studentene som vil ta Kunnskapsspillet i bruk i egen undervisning, knytter seg til erfaringer fra egen læringsprosess. Flere av studentene etterspør at emneleder kan lage flere spill. I oppsummeringen fra gruppeevalueringen fremgår følgende: «Vi vil ha lek og spill til flere temaer slik som i Kunnskapsspillet. Det er bra repetisjon på hva som er gjennomgått i fellesforelesningene i pedagogikk». Dette viser at studentene har erfart Kunnskapsspillet som et fleksibelt multiverktøy for læring, et artefakt for læring som er relevant både $\mathrm{i}$ eget studie og $\mathrm{i}$ et fremtidig virke som lektor i ulike fag. 


\section{KUNNSKAPSSPILLET PÅ LEKTORUTDANNINGA - VIDERE UTVIKLING}

I følge Beavis et al. (2014) undervurderer gjerne undervisere den rollen de selv har i spillbasert læring, noe som kan svekke spillet som læringsmetode. Konklusjonen til Beavis et al. er at lærerens rolle i spillbasert læring er sentral. En av de viktigste oppgavene underviseren har ved bruk av spillbasert læring, er å sikre at spillet ikke er en frittstående aktivitet, men inngår som en integrert del av læringsprosessen (Beavis et al., 2014). Det er potensiale for videre utvikling i alle de tre fasene i læringsprosessen ved bruk av Kunnskapsspillet.

Forberedelsene til spillingen, når studentene lager spørsmål til spillet, kan for det første styrkes. En av studentene trakk frem at det kan være vanskelig å spille uten en fasit: «God læring. Eneste utfordring kan være at hvis ingen har et bra svar er det vanskelig å bedømme uten løsningsforslag eller stikkord.» I Kunnskapsspillet er det pensum som er fasiten i spillet, og studentene må anstrenge seg for å hente frem kunnskap, både når de svarer og bedømmer andres svar (jmf. Kirk-Johnsen et al., 2019). Et resultat det i så måte er verdt å se litt nærmere på er studentene tilfredshet med eget arbeid med pensum. Av de 275 studentene som svarte på dette spørsmålet er det $45 \%$ som er «Mindre tilfreds» med eget arbeid med pensum, $47 \%$ er «Tilfreds» og $8 \%$ er «Svært tilfreds» (Tabell 7). I fortsettelsen vil vi stimulere til mer aktiv bruk av pensumlitteraturen når studentene lager spørsmål til Kunnskapsspillet. En måte å gjøre dette på, er at studentene setter referanse med sidehenvisning til pensum etter spørsmålet på spillkortet.

Også selve spillseansen kan videreutvikles. Vi vil legge til rette for at studentene spiller spillet flere ganger i løpet av semesteret, når to kategorier og når tre kategorier spillkort er produsert. Dette vil føre til at spillet blir tettere integrert $\mathrm{i}$ undervisningen og i studentenes læringsprosess gjennom semesteret. Vi ser også at det vil være en styrke å ha flere undervisere til stede under spillseansen. På lektorutdanninga har spillet vært brukt i studentkull på over 100 studenter, og enkelte ganger med bare en lærerressurs tilgjengelig. Med større lærertetthet, vil undervisere i større grad kunne være stillas for studentene i den proksimale utviklingssonen ved å delta i diskusjoner og svare på spørsmål.

Når det gjelder den tredje og siste fasen, etterarbeid, er det også et potensiale for å styrke studentenes læringsutbytte. Etter at studentene har spilt spillet kan det for eksempel være relevant å reflektere over egen læringsprosess i lys av ulike læringsteorier som sosiokulturell læringsteori, behaviorisme og kognitiv læringsteori. Det kan også være relevant å diskutere forholdet mellom læringsmiljø og læringsutbytte og variasjoner i studenters tilfredshet med å spille Kunnskapsspillet. Beavis et al. (2014) peker på farene ved å anta at spill er universelt engasjerende, uten å ta hensyn til mangfoldet $\mathrm{i}$ studentgruppen og andre forhold i det sosiale læringsmiljøet. For de kommende lektorene er dette diskusjoner med stor grad av profesjonsrelevans. 


\section{KONKLUSJON}

I revideringen av pedagogikkemnet førstesemester ble det høsten 2017 gjort omfattende endringer. Ambisjonen var å styrke studentenes trivsel og trygghet, samt skyte fart og gi retning på studentenes profesjonsutvikling og utvikling av identitet som lektor gjennom et mer helhetlig sammenhengende og profesjonsrelevant emne. Undervisningsmetoder ble endret med innføring av spillbasert læring. Evalueringer fra kull 2017, 2018 og 2019 viser en styrking av det sosiokulturelle læringsmiljøet ved utdanninga. De fleste studentene har funnet sin plass på lektorutdanninga. De jobber sammen i grupper, og har lærere og medstudenter de kan snakke fortrolig med dersom de har behov for det. Vi vurderer at endring i undervisningsmetoder ved innføring av spillbasert læring har bidratt positivt. I artikkelen har vi diskutert studentenes evalueringer av Kunnskapsspillet i lys av kvalitetsdimensjoner som læringslyst, læringsutbytte og opplevelse av meningsfull sammenheng. Eksterne sensorer bekrefter at studentene presterer på et høyt nivå og at de er godt i gang med sin profesjonsutvikling etter bare fire måneder på utdanninga. Spillet har også fungert som noe mer enn at studentene har lært pedagogisk teori. Det har modellert undervisning og er profesjonsrelevant, og studentene oppgir at de også vil ta Kunnskapsspillet i bruk i egen undervisning.

Hovedinntrykket er at Kunnskapsspillet strukturerer arbeidet med pensum for både foreleser og student og også for sensor. Studentene er engasjerte og de gir uttrykk for læringslyst. Det er liten forskjell mellom de tre kullene. Kull 2017 er litt mer tilfredse med bruk av spillet, ser litt større potensiell nytte frem mot eksamen og har også flest positive ytringer i sine fritekstsvar sammenlignet med studentene i kull 2018 og kull 2019. Kull 2017 var også det kullet som tok spillet mest i bruk. Økt frekvens i bruk av spillet, og mer aktivt bruk av pensum i spillets ulike faser, vil være viktig for å bidra til en ytterligere styrking av studentenes læringsutbytte ved bruk av Kunnskapsspillet.

\section{LITTERATUR}

Agarwal, P., Bain, P. \& Chamberlain, R. (2012). The Value of Applied Research: Retrieval Practice Improves Classroom Learning and Recommendations from a Teacher, a Principal, and a Scientist. Educational Psychology Review, 24(3), 437-448. doi:10.1007/s10648-012-9210-2

Agarwal, P. (2019). Retrieval Practice \& Bloom's Taxonomy: Do Students Need Fact Knowledge Before Higher Order Learning? Journal of Educational Psychology, 111(2), 189-209. doi:https://psycnet.apa.org/doi/10.1037/edu0000282

Askling, B., Dahl, T., Heggen, K., Kuldbrandstad, L. I., Lauvdal, T., Maursethagen, S., Qvortrup, L., Salvanes, K., Skrøvset, s. og Thue, F. W. (2015). Ekspertgruppe om lcererrollen. Et kunnskapsgrunnlag. Fagbokforlaget

Bandura, A. (1997). Self-efficacy: The exercise of control. W H Freeman/Times Books/ Henry Holt \& Co.

Beavis, C., Rowan, L., Dezuanni, M., Mcgillivray, C., O’Mara, J., Prestridge, S. \& Zagami, J. (2014). Teachers' beliefs about the possibilities and limitations of digital games in classrooms. E-Learning and Digital Media, 11(6), 569-581. https://doi.org/10.2304/elea.2014.11.6.569

Biggs, J. B. (2003). Aligning Teaching for Constructing Learning.

https://www.heacademy.ac.uk/sites/default/files/resources/id477_aligning_teaching_for_constructing_learning.p df

Biggs, J. B. \& Tang, C. (2011). Teaching for Quality Learning at University. Open University Press

Bjørndal, C. R. P. (2015). Det vurderende øyet. Observasjon, vurdering og utvikling i undervisning og veiledning. Gyldendal Akademisk.

Blanchard, O. \& Buchs, A. (2015). Clarifying Sustainable Development Concepts Through Role-Play. Simulation \& Gaming, 46(6), 697-712. https://doi.org/10.1177/1046878114564508 
Boghian, I., Cojocariu, V.-M., Popescu, C. V. \& Mata, L. (2019). Game-based learning. Using board games in adult education. Journal of Educational Sciences \& Psychology, 9(1), 51-57.

Bridge, D. (2014). You Sunk My Constitution: Using a Popular Off-the-Shelf Board Game to Simulate Political Concepts. Journal of Political Science Education, 10(2), 186-203. https://doi.org/10.1080/15512169.2014.894363

Clapper, T. C. (2015). Cooperative-Based Learning and the Zone of Proximal Development. Simulation \& Gaming, 46(2), 148-158. https://doi.org/10.1177/1046878115569044

Crookall, D. (2010). Serious Games, Debriefing, and Simulation/Gaming as a Discipline. Simulation \& Gaming, 41(6), 898-920. https://doi.org/10.1177/1046878110390784

Dysthe, O. (2013). Dialog, samspill og læring. Flerstemmige læringsfellesskap i teori og praksis. I R. J. Krumsvik \& R. Säljö (red.) Praktisk- pedagogisk utdanning. En antologi. Fagbokforlaget.

Esarey, J. \& Valdes, N. (2020) Unbiased, reliable, and valid student evaluations can still be unfair, Assessment \& Evaluation in Higher Education, 45:8, 1106-1120, DOI: 10.1080/02602938.2020.1724875

Garris, R., Ahlers, R. \& Driskell, J. E. (2002). Games, motivation, and learning: A research and practice model. Simulation \& Gaming, 33(4), 441-467. https://doi.org/10.1177/1046878102238607

Hammerness, K. (2012). Examing Features of Teacher Education in Norway. Scandinavian Journal of Educational Research. Vol. 57 No. 4, 400-419. https://doi.org/10.1080/00313831.2012.656285

Haug, P. (2013). Tilpasset opplæring for den enkelte i fellesskapet. I R. J. Krumsvik \& R. Säljö (red.) Praktiskpedagogisk utdanning. En antologi. Fagbokforlaget.

Heggen, K. \& Raaen, F. D. (2014). Koherens i lærarutdanninga. Norsk Pedagogisk Tidsskrift. Vol. 98 No. 1, 313.

Hoy, B. (2018). Teaching History With Custom-Built Board Games. Simulation \& Gaming, 49 (2), $115-133$. https://doi.org/10.1177/1046878118763624

Jakobsen, A. N \& Waldenstrøm, L (2017). Fra lærerstyrt undervisning til varierte læringsformer. Nordic Journal of STEM Education, Vol. 1 No. 1, 319-327

Järvinen, M. \& Mik-Meyer, N. (red.) (2017). Kvalitativ analyse. Syv traditioner. København: Hans Reitzels Forlag

Karpicke, J. \& Grimaldi, P. (2012). Retrieval-Based Learning: A Perspective for Enhancing Meaningful Learning. Educational Psychology Review, 24(3), 401-418. doi:10.1007/s10648-012-9202-2

Kirk-Johnson, A., Galla, B. M., \& Fraundorf, S. H. (2019). Perceiving effort as poor learning: The misinterpretedeffort hypothesis of how experienced effort and perceived learning relate to study strategy choice. Cognitive Psychology, 115, 101237. doi:https://doi.org/10.1016/j.cogpsych.2019.101237

Kunnskapsdepartementet (2015). NOU 2015:8 Fremtidens skole - Fornyelse av fag og kompetanser. https:/www.regjeringen.no/contentassets/da148fec8c4a4ab88daa8b677a700292/no/pdfs/nou201520150008 000dddpdfs.pdf

Lun, K. A. W., Chi, L. S. \& Hun, L. S. W. (2018). The learning benefits of teaching: A retrieval practice hypothesis. Applied Cognitive Psychology, 32(3), 401-410. doi:doi:10.1002/acp.3410

Lytra, V. (2015). Playful Talk, Learners' Play Frames and the Construction of Identities. Discourse and Education, 3, 1-12. https://doi.org/10.1007/978-3-319-02322-9 13-1

Miller, G. A. (1956). The magical number seven, plus or minus two: some limits on our capacity for processing information. Psychological Review, 63(2), 81-97. https://doi.org/10.1037/h0043158

Nasjonalt råd for lærerutdanning (2017). Nasjonale retningslinjer for lektorutdanning for trinn 8-13

Nicholson, S. (2011). Improving the Trivia Game Model Creating Original Games. Knowledge Quest, 65(1), 6065.

Nicholson, S. (2012). Completing the Experience: Debriefing in Experiential Educational Games. The 3rd International Conference on Society and Information Technologies, 11(6), 117-121.

Pettersen, R. (2005). Kvalitetslcering $i$ høyere utdanning. Innføring i problem og praksisbasert didaktikk. Universitetsforlaget

Pieter, S., Brockx, B., \& Mortelmans, D. “On the Validity of Student Evaluation of Teaching: The State of the Art." Review of Educational Research 83, no. 4 (December 2013): 598-642. https://doi.org/10.3102/0034654313496870.

Plass, J. L., Homer, B. D. \& Kinzer, C. K. (2015). Foundations of Game-Based Learning, 50(4), $258-283$. https://doi.org/10.1080/00461520.2015.1122533

Prince, M. (2004). Does active learning work? A review of the research. Journal of Engineering Education, 93(July), 223-231. https://doi.org/10.1038/nature02568 
Prøitz, T. S. (2016). Læringsutbytte slik lærere, forskere og politikere ser det. Utdanningsnytt.no https://www.utdanningsnytt.no/laereryrket-pedagogikk-skoleutvikling/laeringsutbytte-slik-laerere-forskereog-politikere-ser-det/144679

Richland, L. E., Kornell, N., \& Kao, L. S. (2009). The pretesting effect: Do unsuccessful retrieval attempts enhance learning? Journal of Experimental Psychology: Applied, 15(3), 243-257. https://doi.org/10.1037/a0016496

Ryan, R. \& Deci, E. (2000). When rewards compete with nature: The undermining of intrinsic motivation and selfregulation. I C. Sansone \& J. Harackiewich (ed): Intrinsic and extrinsic motivation: The search for optimal motivation and performance. San Diego, CA: Academic Press.

Skrøvset, S. Eriksen, A. Leming T. \& Tobiassen, A. K. (2017). Rapport-Oppstart med STIL. Laringslyst og loeringsbehov. ProTed, Institutt for lærerutdanning og pedagogikk, UiT. Refr. nr. 2018-72-1

Skaalvik, E. M. \& Skaalvik, S. (2014). Skolen som loeringsarena. Selvoppfatning, motivasjon og laring. 2. utgave. Universitetsforlaget.

Säljö, R. (2013). Støtte til læring - tradisjoner og perspektiver. I R. J. Krumsvik \& R. Säljö (red.) Praktiskpedagogisk utdanning. En antologi. Fagbokforlaget.

Spooren, P., Brockx, B., \& Mortelmans, D. (2013). On the Validity of Student Evaluation of Teaching: The State of the Art. Review of Educational Research (Vol. 83). https://doi.org/10.3102/0034654313496870

Sæthre, H. Å. (2014) A tilrettelegge for at studentene skal lykkes. Bergen: Haas1 - forlag

Thagaard, T. (2013). Systematikk og innlevelse en innføring i kvalitativ metode. Fagbokforlaget.

Uttl B, White CA, Gonzalez DW (2017). Meta-analysis of faculty's teaching effectiveness: student evaluation of teaching ratings and student learning are not related. Studies in Educational Evaluation (54), 22-42. doi: 10.1016/j.stueduc.2016.08.007.

Vygotskij, L. (1978). Mind in Society: The Development of Higher Psychological Processes. M. Cole, V. JohnSteiner, S Schribner \& E. Souberman (ed). Camebridge, Ma./London: Harvard University Press.

Vygotskij, L. (2001). Tenkning og Tale. A. Kozulin (red). Oslo: Gyldendal Akademiske.

Wang, G., \& Williamson, A. (2020). Course evaluation scores: valid measures for teaching effectiveness or rewards for lenient grading? Teaching in Higher Education. https://doi.org/10.1080/13562517.2020.1722992

Wiggins, B. E. (2016). An Overview and Study on the Use of Games, Simulations, and Gamification in Higher Education. International Journal of Game-Based Learning, 6(1), 18-29. https://doi.org/10.4018/ijgbl.2016010102 